\title{
De CURAÇAOSCHE BEGROOTING VOOR 1928 \\ DOOR
}

\author{
MR. B. DE GAAY FORTMAN
}

Autonomie, vooral in verband met het politievraagstuk en een sluitende begrooting, het beleid van den gouverneur en de onderwijsgelijkstelling, ziet hier de drie voornaamste onderwerpen van debat bij deze begrooting. Als nooit tevoren binnen afzienbaren tijd is deze begrootingsbehandeling een tijd van spanning geweest. Vooral in de Tweede Kamer hebben leden van nagenoeg alle partijen een tot nu toe ongekende belangstelling in de vraagstukken, die Curaçao beroerden, getoond. Men had zich in de kwesties ingewerkt, zelfs zoo dat niet, als reeds zoo dikwijls, men bij de repliek verlegen stond bij gebreke van betere kennis van zaken dan de minister had. Trouwens deze laatste viel niet altijd mee, hetgeen te opmerkelijker was, nu de heer Bijleveld zich tot tolk maakte der reeds eerder gehoorde klacht, dat de gouverneur den schijn wekte, vaak in hoofdzaak de bevelen van Den Haag uit te voren. Zoo kon de heer Joekes niet aanstonds worden te woord gestaan over de voorwaarden, waarop domeinland aan de Caracasbaai aan de C. P. I. M. was afgestaan. Op de klachten van den heer De Jong in de Eerste kamer over het tekort aan woningruimte en op diens vragen, of op Curaçao niet een commissie benoemd was om ter zake van advies te dienen? of dat advies was uitgebracht? en hoe het luidde? kwam geen bescheid, alleen verklaarde de minister een bijzondere commissie niet noodig. Natuurlijk niet: die commissie is er geweest en heeft een rapport uitgebracht, dat niet opgevolgd is, met dit gevolg, dat de berichten in de plaatselijke pers en die men uit brieven en andere mededeelingen krijgt, heel wat min- 
der optimistisch luiden dan die, welke de minister van den gouverneur en van andere bewoners van Curaçao had. Een derde voorbeeld: de heer De Jong had ook gesproken over het ontbreken van voldoende bevolkingsregisters op Curaçao - de minister zei wel, dat deze zaak , uiteraard" de aandacht had, maar niet, dat bij de begrooting voor 1929 gelden voor dit doel waren aangevraagd.

Er werd dus ditmaal gerepliceerd in de Tweede Kamer De nog bepaald strijdlustige stemming scheen iets matter, maar na eenige dagen respijt trok men bij de artikelen andermaal zoo forsch van leer, dat de minister belangrijke concessies moest doen, om zijn begrooting, formeel ongewijzigd, binnen te halen. Ondanks de krachtige oppositie èn tegen des ministers èn tegen des gouverneurs beleid stond het debat hoog. Zoozeer onthield men zich van persoonlijkheden in zoo uitermate den persoon dezer bewindslieden rakende kwesties, dat een parlementaire veteraan, die wat laat de Kamer binnenstapte aan een zijner medeafgevaardigden kon vragen: wie toch wel die gouverneur was, wiens bestuur zoo algemeen afgekeurd werd? Slechts scheen de minister even uit den toon te vallen, toen hij particuliere bijzonderheden uit des gouverneurs leven meedeelde, die in het debat geen waarde hadden, omdat niemand bezwaren van dien aard had gemaakt, en daaraan verbond een opmerking over de ,standing” van den landvoogd, die met nauw verholen vroolijkheid werd ontvangen door hen, voor wie zij rechtstreeks bestemd was, en ook elders juist om de voor de hand liggende verklaring, die de minister ervan gaf in de Eerste Kamer, zeker niet het bedoelde gevolg zal hebben. Ook hier stuit men op een onverwacht gebrek aan kennis van de Curaçaosche maatschappij en haar gevoeligheden. In het Voorloopig verslag der Eerste Kamer is hiervan iets gezegd.

Soberheid ter zake van dit onderwerp worde dezerzijds betracht en het oordeel'opgeschort. Wat niet goed geweest is of nòg verkeerd moge zijn, kan voor de toekomst verbeterd worden, en wij hebben de toezegging van den mi- 
nister, ,dat, wanneer binnen zekeren tijd niet mocht blijken, dat de gang van zaken bevredigender is dan door vele leden wordt geoordeeld, ik dan zeer zeker zal weten, wat mij te doen staat."

De autonomie. De Koloniale Raad had van een ontwerp-begrooting met een tekort van bijna $f$ 1.100.000.waarvan $f 900.000$. - door leening te dekken, een sluitende begrooting gemaakt met een overschot van $f$ 15.000.- door maar even bij amendement $f 1.150 .000$. - te schrappen, waaronder de bijdrage aan de Nederlandsche schatkist voor de kosten der landmacht in verband met de reorganisatie der politie, ruim $f 600.000$.- voor nieuwe werken, $f$ 240.000. - voor de waterleiding en $f$ 120.000. - voor duurtbijslagen. In aaneengesloten slagorde trok de Raad tegen den eenigen bestuursgemachtigde, den administrateur van financiën, op. Nagenoeg alle amendementen werden met algemeene stemmen aangenomen. Het was bekend, dat de Raad gekant was tegen een militaire politie en de consequentie daarvan bracht de schrapping van den eersten post mee. Voor de nieuwe werken wilde men geen gelden toestaan bij onbekendheid met de plannen van het bestuur. Wat de watervoorziening betreft werd $f 260.000$. voldoende geacht naast de $f 500.000$.- , van het loopende jaar (1927) nog beschikbaar, en met handhaving van des gouverneurs recht om de bezoldigingen te regelen wilde de Raad eerst vernemen, welk bedrag voor elke bepaalde betrekking verlangd werd, alvorens een totaalsom beschikbaar te stellen.

De minister heeft nagenoeg al deze posten hersteld, zij het ook, dat van die voor de havenverbetering (nieuwe werken) en de watervoorziening memorieposten werden gemaakt. De bouw van een nieuw postkantoor werd afgevoerd, omdat deze niet met den bouw van een nieuw belastingkantoor in hetzelfde jaar zou kunnen worden volbracht. De bijdrage voor de kosten van het garnizoen werd van 50 op $25 \%$ gebracht.

Tegen dit ministerieel beleid zijn bezwaren geopperd in beide Kamers. Maar ook het optreden van den Raad is niet zonder bedenking. Zóó kan men wel altijd sluitende 
begrootingen maken. De Raad beval zelf suppletoire begrootingen voor de $z$. i. nog niet voldoende voorbereide en uitgewerkte plannen aan. Het kan staatsrechtelijk misschien een belangwekkende vraag worden: wat gebeuren moet met suppletoire verhoogingen van sluitende begrootingen, die door de verhooging niet sluitend meer zijn? Zullen die wel in de Staten-Generaal moeten komen?

De bezwaren tegen het ingrijpen van den minister, nu eenmaal een sluitende begrooting verkregen was, zijn m. i. niet geheel juist. Vooreerst was er, gelijk uit het bovenstaande blijkt, feitelijk geen sluitende begrooting. De heer Droogleever Fortuyn wees er op. En wat betreft de militaire politie was er een door de Staten-Generaal aanvaard besluit, dat door den Kolonialen Raad eenvoudig op zij gezet was. De fout van Mr. Joekes was dan ook, dat hij met zijn amendement de door den Kolonialen Raad in plaats van de militaire-politie-posten opgebrachte uitgaven voor een burgerpolitie herstellen wilde. Hier stond de minister sterk met zijn argument, dat hij wel aldus had moeten handelen in vervolg op het een jaar tevoren aangenomen stelsel. Maar's ministers tegenstanders hadden ook sterker argumenten. Vooreerst dat, ontleend aan art. 99 van het regeeringsreglement, dat de kosten van de rijkslandmacht ten laste van het moederland komen. Dan het door Mr. Bijleveld gedane beroep op art. 176, dat blijkens de memorie van toelichting zou beteekenen, dat het garnizoen geen politiediensten moet verrichten. En ten slotte de vooral door Mr. Beumer ontwikkelde staatsrechtelijke bezwaren tegen het inmiddels afgekomen Koninklijk besluit tot regeling der militaire politie, dat den procureur-generaal eenvoudig onthief van zijn taak als hoofd der politie volgens het regeeringsreglement. De aard dezer bezwaren maakte echter, dat dit onderwerp zich veel meer leende tot een interpellatie of tot een uitspraak bij motie dan tot een behandeling bij de begrooting. En zoo moest het amendement-Joekes wel vallen, gelijk geschiedde met 50 tegen 26 stemmen. Intusschen heeft de minister principieele wijziging van het 
koninklijk besluit, met behoud natuurlijk van het wezen der militaire politie, moeten toezeggen, en ten deele is die, blijkens mededeeling in de Eerste Kamer, tot stand gekomen. Verder is de minister nog gegaan naar aanleiding van de klacht omtrent het niet ten einde gevoerde overleg met den raad. Hij heeft ook toegezegd een nieuw overleg met den kolonialen Raad ,op een wijze, waarbij groote tegenmoetkomendheid zal worden betracht eventueel ook op andere punten dan door den afgezant zijn ter sprake gebracht." Deze afgezant, de ook als vertrouwensman van den Kolonialen Raad aangeduide oud-raadsvoorzitter, de heer A. G. Statius Muller, had zoodanige mededeelingen aan den minister gedaan, door dezen weer in de Tweede Kamer meegedeeld, dat aan onverzettelijkheid van die zijde geenszins mag worden gedacht. Er is dus alle hoop, dat deze zaak tot een bevredigend einde zal worden gebracht.

In zijn verdediging van de koloniale autonomie wees $\mathrm{mr}$. Bijleveld er slagvaardig op, dat de minister van de gelegenheid der niet-goedkeuring van de voorloopige begrooting om de politiekwestie had gebruik gemaakt om tevens andere wijzigingen aan te brengen, die op zichzelf niet tot onthouding der koninklijke goedkeurig zouden geleid hebben. Hiervan had de minister niet terug.

Ook in de Eerste Kamer is de autonomie ter sprake gekomen. De minister heeft zich in de memorie van antwoord beroemd op „zijn voortdurend streven om ten volle recht te doen wedervaren aan het beginsel, belichaamd in artikel 61 der herziene Grondwet." Dit ware te loffelijker, nu onze Westindische gebiedsdeelen nog steeds op uitvoering der grondwetsherziening wachten. In de Eerste Kamer kon de minister meedeelen, dat het advies van Mr. Brantjes over de voorstellen van de commissieStaal, waarop het wachten was, binnengekomen is.

De onderwijsgelijkstelling is in Curaçao niet ter sprake gekomen. De Koloniale Raad is er geen voorstander van, gelijk meermalen gebleken is. Ook de gouverneur schijnt dit niet te zijn. Maar de heer Van Vuuren bracht haar in de Tweede Kamer ter sprake en de heer De Jong in de 
Eerste Kamer. Het pleidooi, daar verleden jaar door Mr. Anema gehouden, had niets uitgehaald. Een vraaggesprek van den gouverneur met het Handelsblad en een uitlating van den minister, het vorige jaar in de Eerste Kamer op gezag van den gouverneur gedaan, gaf den heer Van Vuuren meer dan voldoende stof, om op soms heftige wijze tegen beide bewindsmannen op te trekken. Wij vermelden alleen het resultaat. De heer Van Vuuren had een beslist antwoord verlangd op de vraag, of de Kamer absoluut zeker kon zijn, dat bij de begrooting voor 1929 op voorstellen zou zijn te rekenen, die de gelijkstelling nader brengen, en dat bij die begrooting althans eenige desiderata zouden worden verwezenlijkt. In eersten termijn beloofde de minister zoo ver te zullen gaan, als mogelijk zou zijn bij een sluitende begrooting, en zoover als uitvoerbaar zou zijn na overleg met den minister van financiën bij een niet sluitende begrooting. Dit antwoord bevredigde den heer Van Vuuren niet, en bij de artikelsgewijze behandeling drong hij den minister zich los te maken van de door dezen gestelde voorwaarden, dreigende met een stemmen door de R. K. afgevaardigden tegen de begrooting. Het zag er inderdaad dreigend uit. De socialisten zouden ook tegenstemmen, en nagenoeg alle R. K. hadden de presentielijst geteekend. Toen sprak de minister het voor hemzelf verlossende woord: „Het was mijn voornemen, in verband met de toezegging, die ik de vorige week heb gedaan, de aandacht van den Gouverneur te vestigen op de hier uitgesproken wenschen en op de door mij in verband daarmede gedane toezegging, en dat zal ik ook uitvoeren. Mocht de Koloniale Raad in dit opzicht bezwaar maken .... dan zal ik niet mij daarbij neerleggen, maar wel zeer zeker blijven bevorderen, dat, overeenkomstig mijn pertinente toezegging, een nadere schrede wordt gedaan in de door de wet voorgeschreven gelijkstelling van het bijzonder en het openbaar onderwijs...." En in de Eerste Kamer is de minister zoo mogelijk nog verder gegaan, en heeft toegezegd een uitvoering der gelijkstelling ,,in zoo snel mogelijk tempo."

Ongetwijfeld is de vrucht van deze begrootingsbehan- 
164 DE CURAÇAOSCHE BEGROOTING VOOR 1928

deling hierin te zien: indiening van een sluitend begrootingsontwerp voor 1929 door den gouverneur bij den Kolonialen Raad;

uitbreiding van den gouvernementssteun aan het bijzonder onderwijs;

ongewijzigde aanvaarding van het ontwerp door den Kolonialen Raad.

Amsterdam 14 Mei 1928. 